\title{
ASSESSMENT OF INDIVIDUAL DOSE EQUIVALENTS Hp(0.07) OF MEDICAL STAFF OCCUPATIONALLY EXPOSED TO IONIZING RADIATION IN 2012
}

\author{
OCENA WIELKOŚCI INDYWIDUALNYCH RÓWNOWAŻNIKÓW DAWEK Hp $(0,07)$ U PRACOWNIKÓW MEDYCZNYCH \\ ZAWODOWO NARAŻONYCH NA DZIAŁANIE PROMIENIOWANIA JONIZUJĄCEGO W 2012 ROKU
}

Nofer Institute of Occupational Medicine / Instytut Medycyny Pracy im. prof. J. Nofera, Łódź, Poland

Department of Radiation Protection / Zakład Ochrony Radiologicznej

\begin{abstract}
Background: The paper presents the Nofer Institutes of Occupational Medicine in Łódź's results of the assessment of individual dose equivalents $\mathrm{Hp}(0.07)$ of medical staff exposed to X-rays in Poland in 2012. In addition, the collected data was analysed in terms of types of medical units performing medical procedures and the categorization of personnel. Material and Methods: Dosimetric service was provided for medical staff of interventional radiology departments occupationally exposed to ionizing radiation in terms of individual dose equivalents $\mathrm{Hp}(0.07)$. In 2012, personal dosimetry $\mathrm{Hp}(0.07)$ determinations were performed by the Nofer Institute of Occupational Medicine in Łódź and covered 2044 employees from 174 health facilities. The determinations were performed using thermoluminescence dosimetry according to the procedure accredited by the Polish Centre for Accreditation (document number AB 327). The measurements were performed using ring-dosimeters in the periods of 1 or 2 months. Results: Mean annual individual dose equivalent $\mathrm{Hp}(0.07)$ in 2012 was equal to $3.3 \mathrm{mSv}$ (annual limit for $\mathrm{Hp}(0.07)$ is 500 mSv). The average value of annual individual dose equivalent $\mathrm{Hp}(0.07)$ decreased comparing to the previous year. In 2012 , no single case of exceeding the annual limit for $\mathrm{Hp}(0.07)$ was reported. Data stored in the file indicates that more than $96 \%$ of all of the annual doses did not exceed the level of $10 \mathrm{mSv}$. Conclusions: The analysis of data on occupational exposure to ionizing radiation confirms a stable level of exposure and satisfactory radiological protection in interventional radiology facilities monitored by the Nofer Institute of Occupational Medicine in Łódź in Poland in 2012. Med Pr 2014;65(2):167-171
\end{abstract}

Key words: X-rays, personal dose equivalent, thermoluminescence detector, interventional radiology, ring dosimetry

\begin{abstract}
STRESZCZENIE
Wstęp: W prezentowanej pracy przedstawiono wyniki oceny indywidualnych równoważników dawek Hp(0,07) promieniowania jonizującego u personelu medycznego zakładów radiologii interwencyjnej zawodowo narażonego na promieniowanie rentgenowskie w Polsce w 2012 r. według danych Zakładu Ochrony Radiologicznej Instytutu Medycyny Pracy im. prof. J. Nofera w Łodzi. Ponadto dane zgromadzone w bazie szczegółowo analizowano w zależności od typu oddziału medycznego oraz personelu medycznego. Materiał i metody: Pomiary dozymetryczne dla pracowników zakładów radiologii interwencyjnej zawodowo narażonych na promieniowanie jonizujące prowadzono na podstawie pomiarów indywidualnego równoważnika dawki Hp $(0,07)$. W 2012 r. Instytut Medycyny Pracy im. prof. J. Nofera w Łodzi objął pomiarami 2044 osoby zatrudnione w 174 placówkach służby zdrowia. Badania wykonano techniką dozymetrii termoluminescencyjnej zgodnie z procedurą badawczą (zakres akredytacji AB 327) akredytowaną przez Polskie Centrum Akredytacyjne. Pomiary indywidualnego równoważnika dawki Hp(0,07) wykonywane są w sposób ciągły w cyklach 1-miesięcznych lub 2-miesięcznych. Wyniki: Średni roczny indywidualny równoważnik dawki Hp $(0,07)$ w 2012 r. wynosił 3,3 mSv (roczny limit dla dawki Hp(0,07) wynosi 500 mSv). Średnia wartość rocznego indywidualnego równoważnika dawki $\mathrm{Hp}(0,07)$ zmalała w porównaniu z rokiem poprzednim. W $2012 \mathrm{r}$. nie odnotowano ani jednego przypadku przekroczenia rocznego limitu dla $\mathrm{Hp}(0,07)$. Dane zgromadzone w bazie wskazują, że ponad $96 \%$ wszystkich rocznych dawek $\mathrm{Hp}(0,07)$ nie przekroczyło poziomu $10 \mathrm{mSv}$. Wnioski: Analiza zebranych w bazie Instytutu Medycyny Pracy w Łodzi wyników średnich rocznych dawek $\mathrm{Hp}(0,07)$ w 2012 r. potwierdza ustabilizowany poziom narażenia zawodowego powodowanego promieniowaniem X w zakładach radiologii interwencyjnej. Med. Pr. 2014;65(2):167-171
\end{abstract}

Słowa kluczowe: promieniowanie $\mathrm{X}$, indywidualny równoważnik dawki, dozymetr termoluminescencyjny, radiologia interwencyjna, dozymetria pierścionkowa

Corresponding author / Autorka do korespondencji: Sylwia Papierz, Department of Radiation Protection, Nofer Institute of Occupational Medicine, św. Teresy 8, 91-348 Łódź, Poland, e-mail: spapierz@imp.lodz.pl Received: 2013, November 13, accepted: 2014, January 21 


\section{INTRODUCTION}

In recent years, there has been a rapid development of $\mathrm{X}$-ray techniques as they have been being applied in increasingly diverse and complex procedures, both diagnostic and therapeutic ones. Interventional radiology has been a rapidly growing area of medicine during the last few years because those procedures are typically much less invasive (which means that they are safer for the patient) as well as much less costly than traditional surgery and, that is why, they often replace open surgical procedures. Currently, it is difficult to imagine diagnosis and treatment of many diseases without fluoroscopy-guided procedures.

However, more widespread access to these procedures, due to the long duration of X-ray emission, a large number of archived images and the degree of differentiation are the source of the highest dose which the medical staff are exposed to (1). This causes concerns about the medical personnel's radiation protection during the procedures. For this reason, experts in the field of radiation protection put special emphasis on minimizing the risk of groups of personnel, such as radiologists, physicians, technicians and nurses directly exposed to ionizing radiation. Among others, the International Commission on Radiological Protection (ICRP) has identified fluoroscopy-guided procedures as practices needing a robust radiation protection program (2).

In accordance with the Atomic Law, the assessment of workers' exposure should be performed on the basis of the examination of individual dose measurements (expressed as individual dose equivalent $\mathrm{Hp}(10))$, or dosimetric measurements in the workplace for each calendar year (3). However, in the case of interventional radiology, whole-body dosimetry is not sufficient for medical staff. In this case, the additional legal basis for the examination of individual doses received by critical organs, the skin of the hands of those performing procedures in the field of interventional radiology, is the regulation on the safe handling of radiological equipment (4). One of the basic rules of safe work with X-ray radiation is to measure and compare individual dose limits with the relevant dose limits recommended by international organizations (2). National regulations (5) require the assessment of compliance with those limits to be carried out for each calendar year. Personal monitoring should be based on individual measurements, established by an approved and accredited dosimetric service (3).

In accordance with national regulations, the Department of Radiation Protection of the Nofer Institute of Occupational Medicine in Łódź (Poland) (NIOM) provides the assessment of the medical staff's occupational exposure to X-rays among other dosimetry services. The assessment of workers' occupational exposure to radiation is expressed in terms of individual dose equivalent $\mathrm{Hp}(0.07)$. The measurements are performed using ring-dosimeters (equipped with thermoluminescent detectors) in the periods of 1 or 2 months.

\section{MATERIAL AND METHODS}

The measurements are performed using NIOM ring dosimeters based on two TL detectors (TLD Poland, Kraków). Individual monitoring is based on thermoluminescent MTS-N detectors (LiF: Mg, Ti) sintered in the form of pellets with a $4.5 \mathrm{~mm}$ diameter and $0.9 \mathrm{~mm}$ thickness. The dosimeter comprises a flexible open plastic ring equipped with customer ID, a bar-code and a time interval.

Thermoluminescence is defined as substance luminescence stimulated by light or ionizing radiation released as a result of heating. Thermoluminescent detectors are widely used in radiological protection due to their dosimetric properties, i.e. the fact that the intensity of light emitted during luminescence is proportional to the total dose of ionizing radiation absorbed by the material. Thermoluminescent LiF dosimeter is widely used because it is approximately tissue-equivalent and exhibits good energy-dependent characteristics. The ring has been used for individual monitoring purposes since 2001. All dose measurements have been performed using accredited standard procedures of the Department of Radiological Protection. Dosimeters can be washed and sterilized with the use of common chemicals and for hygiene and epidemiology reasons can be worn under surgical gloves on any finger of the leading hand performing the procedure. They are disposable. All ring dosimeters are worn continuously while medical procedures are carried out. After being worn for a specified period of time, the TLDs are heated and read out in an automatic TL reader. Dosimeter readouts were each time corrected by background readouts.

Dose measurements in terms of the operational quantity of individual dose equivalent $\mathrm{Hp}(0.07)$ for extremity are performed in 1-month or 2-month cycles in the ranges of energy and doses equal to $24-1250 \mathrm{keV}$ and $0.05-5000 \mathrm{mSv}$, respectively. Calibration procedure was performed at the Secondary Standard Laboratory at the Department of Radiation Protection. Irradiations were performed using a Gulmay Medical Ltd. type $320 \mathrm{kV}$ and an irradiator 
type IM6/M with radionuclides ${ }^{137} \mathrm{Cs}$ and ${ }^{60} \mathrm{Co}$ using the ISO rod phantom according to ISO standards (6). Uncertainty of the measurement has been evaluated at $22 \%$ (the assigned expanded uncertainty corresponds to the coverage probability of $95 \%$ and the coverage factor $\mathrm{k}=2$ ). All ring dosimeters are worn continuously while medical procedures are carried out.

\section{RESULTS AND DISCUSSION}

In 2012, the measurements of the doses to the skin of hands performed by the Nofer Institute of Occupational Medicine in Łódź covered 2044 employees (478 women and 1566 men) from 174 health facilities performing procedures in the field of interventional radiology in hospitals, public and private health care centers, institutes, medical clinics and medical centers.
Table 1 shows that (with an accuracy of $0.1 \%$ and corresponding to 2 persons) the percentage distribution of individual dose equivalents for hand was $\mathrm{Hp}(0.07)$ for persons covered by these measurements. It is easy to note that over $10 \%$ of the population receive doses in the range $(1-10) \mathrm{mSv}$, while more than $86 \%$ of the respondents in the range $(0-1) \mathrm{mSv}$. In 2012, the highest recorded annual dose was $363 \mathrm{mSv}$. Unlike in 2011 (when 2 cases were reported (7)), there was no case reported of exceeding the annual dose limit of $\mathrm{Hp}(0.07)$ (the annual limit for $\mathrm{Hp}(0.07)$ is $500 \mathrm{mSv}(5)$ ). In this light, the measured dose for particular individuals was significantly below the indicated limit.

Figure 1 presents the distribution of the annual doses of $\mathrm{Hp}(0.07)$ recorded in the population of medical staff exposed to $\mathrm{X}$ radiation in 2012. According to the presented data, personnel (technicians and nurses)

Table 1. Distribution of individual dose equivalent $\mathrm{Hp}(0.07)$ in the population of health care staff occupationally exposed to $\mathrm{X}$ radiation in 2012

Tabela 1. Rozkład indywidualnych równoważników dawek $\mathrm{Hp}(0,07)$ w populacji pracowników służby zdrowia zawodowo narażonych na promieniowanie rentgenowskie w $2012 \mathrm{r}$.

\begin{tabular}{|c|c|c|c|c|c|c|c|c|c|c|}
\hline \multirow{3}{*}{$\begin{array}{l}\text { Workers } \\
\text { Pracownicy } \\
\text { [n] }\end{array}$} & \multirow{3}{*}{$\begin{array}{l}\text { Laboratories } \\
\text { Zakłady } \\
{[\mathrm{n}]}\end{array}$} & \multirow{3}{*}{$\begin{array}{c}\text { Mean dose } \\
\text { Średnia } \\
\text { dawka } \\
{[\mathrm{mSv}]}\end{array}$} & \multicolumn{8}{|c|}{$\begin{array}{c}\text { People receiving an annual dose within specified range } \\
\text { Osoby, które otrzymały roczną dawkę w poniższych zakresach } \\
{[\%]}\end{array}$} \\
\hline & & & $(0-1]$ & $(1-10]$ & $(10-20]$ & $(20-50]$ & $(50-100]$ & $(100-200]$ & $(200-500]$ & $>500$ \\
\hline & & & \multicolumn{8}{|c|}{$\mathrm{mSv}$} \\
\hline 2044 & 174 & 3.3 & 86.2 & 10.2 & 1.4 & 0.9 & 0.5 & 0.6 & 0.2 & 0.0 \\
\hline
\end{tabular}

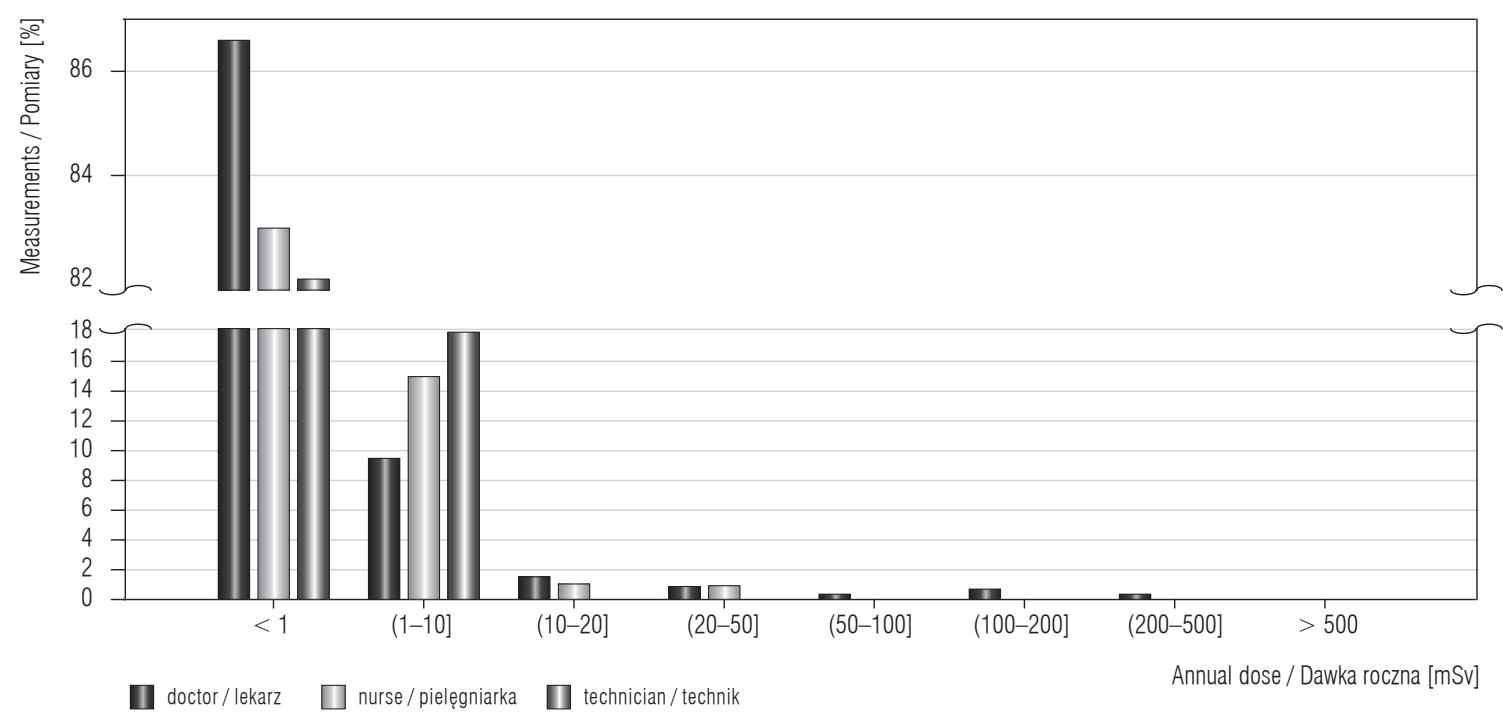

Fig. 1. Distribution of annual individual dose equivalents $\mathrm{Hp}(0.07)$ in the population of medical staff occupationally exposed to X radiation in 2012

Ryc. 1. Rozkład rocznych indywidualnych równoważników dawek $\mathrm{Hp}(0,07)$ w populacji pracowników służby zdrowia zawodowo narażonych na promieniowanie X w 2012 r. 
are much less exposed to ionizing radiation as compared to doctors. This is due to the fact that the former are a lot farther from the X-ray tube and the patient (main scattered radiation source) during medical procedures.

According to the data for 2012, the average annual dose equivalent to the hand of persons occupationally exposed to X-rays was $3.3 \mathrm{mSv}$. In comparison, in 2009, 2010 and 2011 the average annual doses to the hand skin were equal to: $3.8 \mathrm{mSv}, 5.6 \mathrm{mSv}$ and $4.9 \mathrm{mSv}$, respectively (7). Therefore, it can be concluded that the average exposure of the population occupationally exposed to ionizing radiation decreased. The low value of the monitored dose clearly confirms the effectiveness of the implemented system of radiological protection in the laboratories, but this result should be treated with caution because it may also reflect improper use of personal dosimeters in the case of, at least, some doctors.

With the detailed results collected in a database belonging to the Department of Radiological Protection of NIOM it was possible to analyze and classify in detail all of the data in terms of the types of clinical departments of medical units performing medical procedures under the control of ionizing radiation. Personnel were divided into 3 main occupational categories - cardiology, surgery (including orthopedics) and diagnostic imaging (including urology, medical care, interventional endoscopy and others). Figure 2 illustrates the comparison of occupational exposure (the mean annual dose and maximum annual

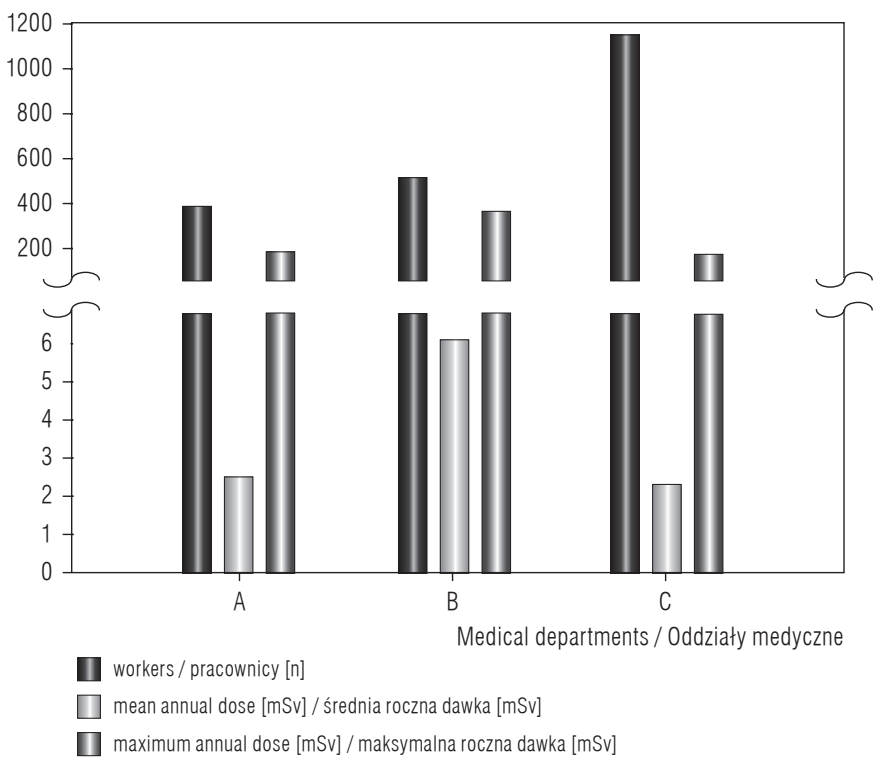

A - cardiology / kardiologia.

B - surgery, including orthopedics / chirurgia i ortopedia.

C - diagnostic imaging / diagnostyka obrazowa.

Fig. 2. Medical staff covered by personal dosimetry $\mathrm{Hp}(0.07)$, the mean and maximum doses in 2012

Ryc. 2. Pracownicy służby zdrowia objęci pomiarami indywidualnych równoważników dawek $\mathrm{Hp}(0,07)$ oraz średnie i maksymalne roczne dawki zmierzone w 2012 r.

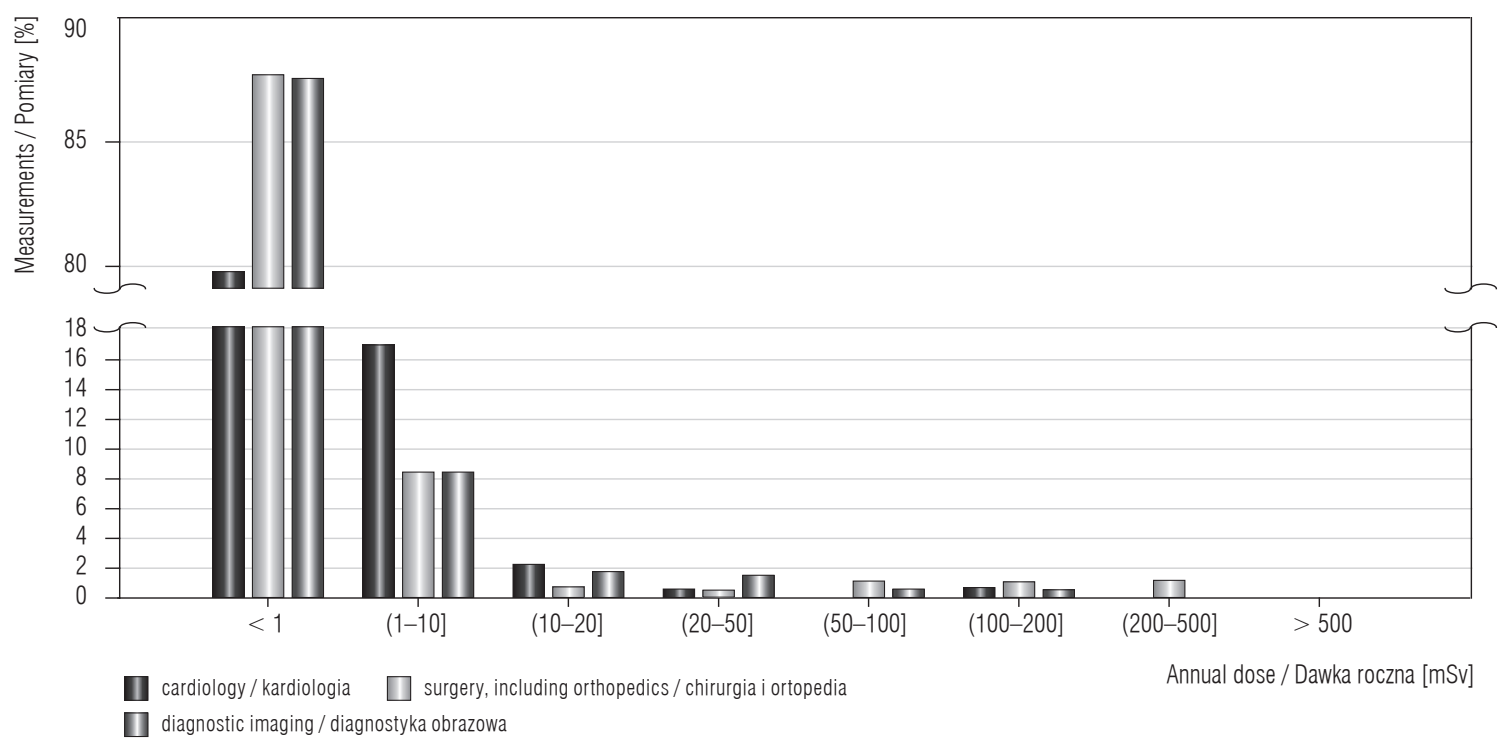

Fig. 3. Frequency distribution of annual individual doses $\mathrm{Hp}(0.07)$ for the various categories of medical staff occupationally exposed to $\mathrm{X}$ radiation in 2012

Ryc. 3. Rozkład rocznych indywidualnych dawek $\mathrm{Hp}(0,07)$ dla różnych kategorii personelu medycznego w populacji pracowników służby zdrowia zawodowo narażonych na promieniowanie X w $2012 \mathrm{r}$. 
dose) depending on the medical category. It can be observed that for the biggest statistical group, i.e. diagnostic imaging (represented by 1148 people), the mean annual dose is very close to the value of exposure for cardiology. Nevertheless, it should be noted that within the group of people performing procedures in the field of surgery, including orthopedics, not only the highest average value, but also the maximum annual dose was recorded.

Figure 3 illustrates the frequency distribution of the annual doses estimated for the skin of hands for the various groups of the medical category. We can observe that the annual doses to the hands never exceed the annual limit in any of the groups. For $1 \%$ (5 people) of the personnel annual doses exceed the 4/10th of the limit in only one group i.e. surgery (including orthopedics). The problem of the occupational exposure of medical personnel is also pointed out in the ORAMED project which was aimed at the radiation protection of the medical staff performing procedures in the field of interventional radiology. According to this work, where attempts were made to estimate the annual dose with regard to the number of procedures performed in the indicated year, $4 \%$ of the respondents receive annual doses exceeding the limit (8).

\section{CONCLUSIONS}

The present study has reported an analysis of the annual individual dose equivalents $\mathrm{Hp}(0.07)$ received by medical staff during medical fluoroscopy-guided procedures. The contrastive analysis of data on occupational exposure to ionizing radiation confirms a stable level of exposure and satisfactory radiological protection in interventional radiology facilities in Poland monitored by the Nofer Institute of Occupational Medicine in Łódź in 2012.

\section{REFERENCES}

1. United Nations Scientific Committee on the Effects of Atomic Radiation (UN). Sources and effects of ionizing radiation. UNSCEAR 2008. Report to the General Assembly with Scientific Annexes. Vol. I. New York: UN; 2010.

2. International Commission on Radiological Protection. The 2007 recommendations of the International Commission on Radiological Protection. ICRP Publication 103. Ann ICRP 2007;37:1-332, http://dx.doi.org/10.1016/j. icrp.2007.11.001.

3. [The Act of 29 November 2000 Nuclear Law consolidated text]. Journal of Laws of 2007 no. 42, item 276 (DzU z 2007 r. nr 42, poz. 1325), as amended Chg. Polish.

4. [Regulation of the Minister of Health of 21 August 2006 on the detailed conditions of safe use of radiological devices]. Journal of Laws of 2006 no. 180, item 1325 (DzU z 2006 r. nr 42, poz. 1325). Polish.

5. [Regulation of the Minister of Health of 18 January 2005 on the ionizing radiation dose limits]. Journal of Laws of 2005 no. 20, item 168. Polish.

6. IEC 4037-3: International Organization for Standardization. X and gamma reference radiation for calibrating dose meters and dose rate meters and for determining their response as function of photon energy. Part 3: Calibration of area and personal dose meters and the measurement of their response as a function of energy and angle of incidence. Geneva: International Organization for Standardization; 1999.

7. Papierz S, Kacprzyk J, Kamiński Z, Adamowicz M, Zmyślony M. Personal dose equivalent $\mathrm{Hp}(0.07)$ of medical personnel occupationally exposed to ionizing radiation during 2001-2011. Med Pr. 2012;63(6):623-7.

8. Vanhavere F, Carinou E, Gualdrini G, Clairand I, Sans Merce M, Ginjaume M, et al. ORAMED: Optimization of Radiation Protection of Medical Staff. EURADOS Report 2012-02. Braunschweig (Germany): European Radiation Dosimetry e.V.; 2012.

\footnotetext{
This work is licensed under a Creative Commons Attribution-NonCommercial 3.0 Poland License / Ten utwór jest dostępny na licencji Creative Commons
} Uznanie autorstwa - Użycie niekomercyjne 3.0 Polska - http://creativecommons.org/licenses/by-nc/3.0/pl/. 